\title{
Survey study of lead exposure among lead workers in Erbil
}

\author{
Ansam Naji Al-Hassani \\ Department of Pharmacology and Toxicology, College of Pharmacy-Hawler University, \\ Erbil, Iraq
}

$$
\frac{\text { Received }}{r .1 \cdot Y \cdot 11} \quad \frac{\text { Accepted }}{r+11 . r \cdot 11}
$$

\section{ABSTRACT}

Objectives: The aim of this work was to assess lead contamination among lead workers in Erbil city.

Patients and methods: This study was carried out on male people working in printing press

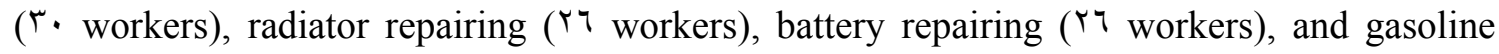
power generator ( ${ }^{\circ}$ o wokers), compared with control group $(r \cdot$ males).

Results: Blood lead levels significantly increased in printing press workers $(P<\bullet . \bullet)$, radiator and battery repairing workers $(p<\bullet \cdot 1)$, while there was non-significant difference in gasoline power generator workers. A significant correlation was found between duration of exposure and blood lead level in all the above groups and there was insignificant correlation between age and blood lead levels.

Conclusion: Lead blood levels in, printing, battery, radiator repairing, and gasoline generator workers were elevated. Blood lead levels correlated with duration of lead exposure in printing, battery, and radiator workers, but not with their ages.

Keywords: Lead exposure, workers, printing, battery, radiator workers.

$$
\begin{aligned}
& \text { الخلاصة } \\
& \text { هدف الاراسة: كان هدف الدراسة هو تقييم التلوث بالرصاص عند الأشخاص المتعرضين للرصاص نتيجة العمل في مدينة } \\
& \text { اربيل . الإئ. } \\
& \text { الأثخاص :ثلاثون رجلا يعملون في المطابع ،ست وعشرون رجلات يعملون في تصليح راديتارات السيارات، ست }
\end{aligned}
$$

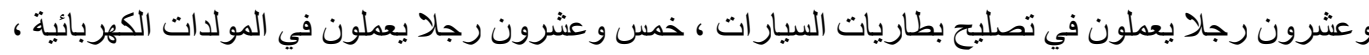

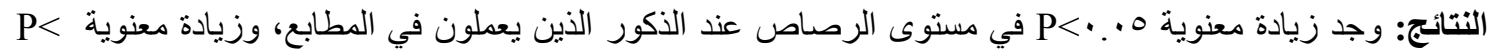

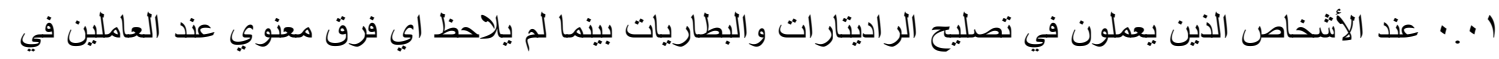

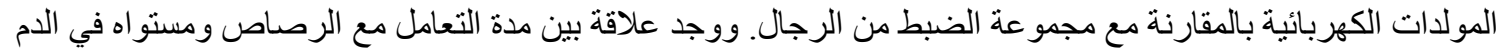

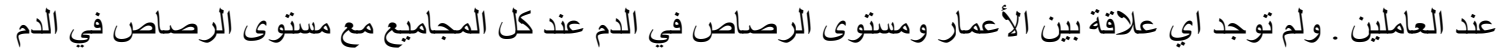

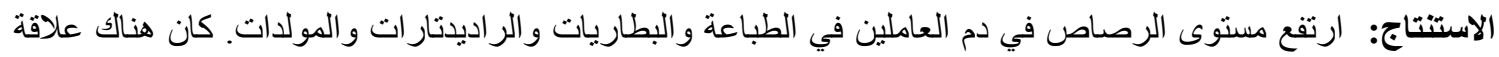

$$
\begin{aligned}
& \text { بين مستوى الدم للرصاص ومدة التعرض ولم يكن هنالك علاقة بين مستوى الرصاص في الدام و وعمر العاملين. }
\end{aligned}
$$

ead is a highly toxic metal that has
been used by humans for over $r . .$. years and is one of the most toxic metals known due to its wide ranging effects on multiple body systems, affecting many processes that are necessary for normal function'. The renal, gastrointestinal, reproductive, central nervous and peripheral nervous systems and the 
biosynthesis of haeme are all adversely affected by lead ${ }^{r}$.

Lead absorption by lungs depends on a number of factors in addition to concentration, these include volume of air respired per day, whether the lead is in particle or vapor form and size distribution of lead-containing particles. Only a very minor fraction of particles over $\cdot{ }^{\circ} \mu \mathrm{m}$ in maximal external diameter are retained in lung but are cleared from the respiratory tract and swallowed. The gastrointestinal absorption of lead is influenced by large number of factors of which age and nutrition which are of particular importance ${ }^{r}$.

Lead is heavily used in industry including batteries, additive to gasoline, paints, explosives, pesticides, soldering, cosmetics, radiation shields, crystal glass, among others ${ }^{\varepsilon}$. However, due to its highly toxic effects, its uses in industry have been highly limited in recent years. Several diseases and syndromes were attributed to lead exposure. The nervous system is the most affected, expressed mostly as sensory deficits and encephalopathy ${ }^{\circ}$, anemia is one of the common symptoms ". Moreover, lead influences the kidney by development of hyperuricemia ${ }^{\gamma}$, and above $\varepsilon \cdot-0$. $\mu \mathrm{g} / \mathrm{dL}$ causes testicular atrophy and hypospermia (lower fertility in men) as well as miscarriage in pregnant woman.

One of the most identified health problems of lead is the deterioration in the bone strength, where $\mathrm{Pb}^{\Upsilon+}$ may replace $\mathrm{Ca}^{r+}$ in the bone mineral phases and causes osteoporosis ${ }^{\wedge}$. Lead may causes mental retardation in children when exposed to more than $\mathrm{r}_{0} \mu \mathrm{g} \mathrm{Pb} / \mathrm{dL}^{\text {? }}$.

Up to $0 . \%$ of inhaled inorganic lead may be absorbed in the lungs. Adults take up $1 .-10 \%$ of lead in food, whereas children may absorb up to $0 . \%$ via the gastrointestinal tract. Lead in blood is bound to erythrocytes, and elimination is slow and principally via urine. Lead is accumulated in the skeleton, and is only slowly released from this body compartment. Half-life of lead in blood is about 1 month and in the skeleton $r \cdot-r$. years'.

The aim of this study was to determine the blood lead levels in printing press workers, radiator repairing workers, battery repairing workers and gasoline power generator workers, in Erbil city, Iraq in order to assess the effects of environmental contamination on the levels of lead in body fluids.

\section{Subjects and methods}

The present study was conducted on workers from several work places where exposed to materials containing lead. The study done between $r \cdot 1 \cdot-r \cdot 11$ in Erbil City. Written agreement informed consents of each workers were obtained. Subjects were categorized into five groups as follows:

- Male control group: This included $r$. apparently healthy male volunteers their ages ranged between $1 \Lambda_{-} 00$ years (mean $\pm \mathrm{SD}$ : $r \pm 11 . \wedge \varepsilon)$, who were not exposed to lead.

- Printing press worker group: This included $r \cdot$ individuals, their ages ranged between $r_{-} 0$ s years (mean $\pm \mathrm{SD}$ : $r \leqslant \pm 1 \cdot .09$ ), who were working in printing and they were mixing, preparing, handing ink of printing and operating the printing machine. The duration of exposure 
ranged between $r_{-} 10$ years (mean \pm SD: ^.r $\stackrel{r}{r} \leqslant r$ ).

- Radiator repairing worker group: This included $Y \tau$ individuals their ages ranged between $r_{-} \circ \leqslant$ years (mean \pm SD: $r \leqslant \pm 1 \cdot .09$ ), who were working in radiator repairing in industrial area, and exposed to lead by inhalation and dermal contact during repairing. The duration of exposure ranged between $r_{-} \mid r$ years (mean $\pm \mathrm{SD}$ : A. \pm . .90$)$.

- Battery repairing worker group: This included $r \checkmark$ individuals, their ages ranged between $I V$ or years (mean \pm SD: $r q \pm l \cdot . \leqslant \varepsilon)$, who were working in lead-acid battery repairing shops. The duration of exposure ranged between r-ls years (mean $\pm \mathrm{SD}: \wedge . \wedge \pm \Upsilon . \vee \tau)$.

- Gasoline power generator worker group: This included ro individuals, their ages ranged between 19_ $\leqslant$ years (mean $\pm \mathrm{SD}$ : $r \cdot \pm r . \wedge v$ ), who were at the gasoline power generator of Erbil city and exposed to lead from gasoline by inhalation and dermal contact. The duration of exposure ranged between $\left.r_{-}\right)$- years (mean \pm SD: T.O. \pm r. Y $\varepsilon)$.

Blood lead levels were determined by "LeadCare ${ }^{\circledR}$ Blood Lead Test System". This test is considered to be appropriate for field studies due to its cost-effective, easy- to-apply, portable features and reliable method '. Samples were collected using all equipment lead free, by a disposable injector, ${ }^{\circ} \mu$ l of blood were drawn by a capillary tube from each worker, and then transferred into a vacuum blood tubes containing ethylenediaminetetraacetic acid (EDTA). The sample was mixes by gently rocking the tube. The tube was left to stand upright for a minute. The prepared samples were deposited onto an electrode strip that is then inserted into analyser. Within three minutes the result appeared on the screen in $\mu \mathrm{g} / \mathrm{dL}$.

The results were analyzed statistically by using the unpaired student's t-test to compare lead levels among worker groups and control group. Correlation coefficient (r) was used to determine the relationship between lead levels and ages or duration of exposure among workers groups.

\section{Results}

Blood lead levels increased significantly in workers within printing presses $\left(10 . Y_{ \pm} \uparrow .00, p<\cdot .00\right)$, radiator ( $Y Y_{ \pm} V_{ \pm} .{ }^{7}, p$

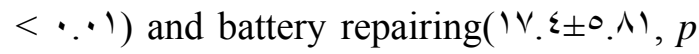
$<\cdot \bullet)$, and non-significantly increased in gasoline power generator workers ( 1$), r \pm r, r \varepsilon)$ as compared with the control group $(\wedge, r \pm 1, r \varepsilon)$.

The mean blood lead levels for radiator and battery repairing workers groups were relatively higher than the blood lead levels of printing press , and gasoline power generator. Table 1 shows the results mentioned above. 
Table '. Blood lead levels (mean \pm S.D., range) of printing press, radiator repairing battery repairing, gasoline power generator workers, and control group

\begin{tabular}{|c|c|c|c|c|c|}
\hline Parameter & $\begin{array}{l}\text { Control } \\
\text { Group } \\
\text { No.=r. }\end{array}$ & $\begin{array}{l}\text { Printing } \\
\text { No. }=r .\end{array}$ & $\begin{array}{l}\text { Radiator } \\
\text { No. }=r q\end{array}$ & $\begin{array}{l}\text { Batteries } \\
\text { No. }=r_{r}\end{array}$ & $\begin{array}{l}\text { Generators } \\
\text { No. }=\text { ro }_{0}\end{array}$ \\
\hline $\mathrm{Pb} \mu \mathrm{g} / \mathrm{dL}$ & $\begin{array}{l}\Lambda . r \pm 1 . r \varepsilon \\
(0.0-1 r . \cdot)\end{array}$ & $\begin{array}{l}10 . Y \\
\pm 7.00 * \\
(V . V-r . T . Y)\end{array}$ & $\begin{array}{l}r Y . V \\
\pm \nearrow .79 * * \\
\left(9 . \leqslant \_r \leqslant .9\right)\end{array}$ & $\begin{array}{l}\mid \vee . \Sigma \\
\pm 0 . \wedge \mid * * \\
(\vee . \vee-r \cdot . q)\end{array}$ & $\begin{array}{l}M, Y \pm Y . r \varepsilon \\
(Y . Y-1 T . Y \varepsilon)\end{array}$ \\
\hline
\end{tabular}

Figures ', $r, r$ and $\varepsilon$ show significant correlation between the duration of exposure and blood lead levels for printing press $(p<\because \cdot)$, radiator repairing $(p<$ $\because \cdot)$, battery repairing $(p<\cdot \cdot 1)$, and gasoline power generator $(p<\because \cdot 0)$ workers groups. While, there was nonsignificant correlation between the age and blood lead levels in the workers and control

groups.

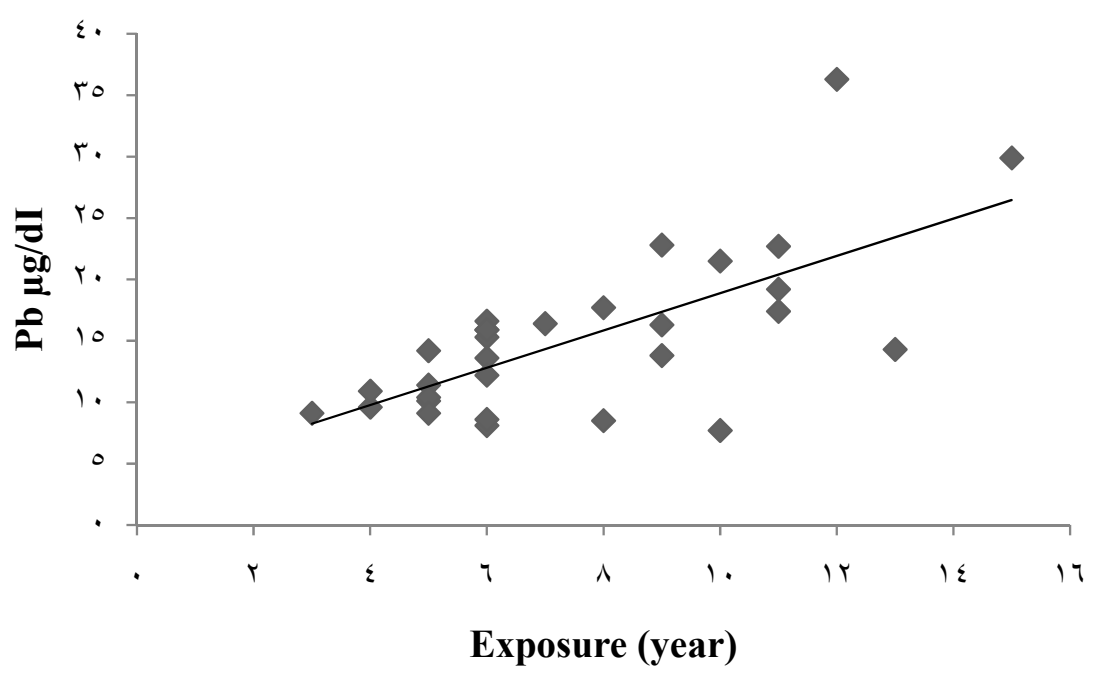

Figure 1. Correlation coefficient between blood lead levels and duration of exposure in printing press worker group 


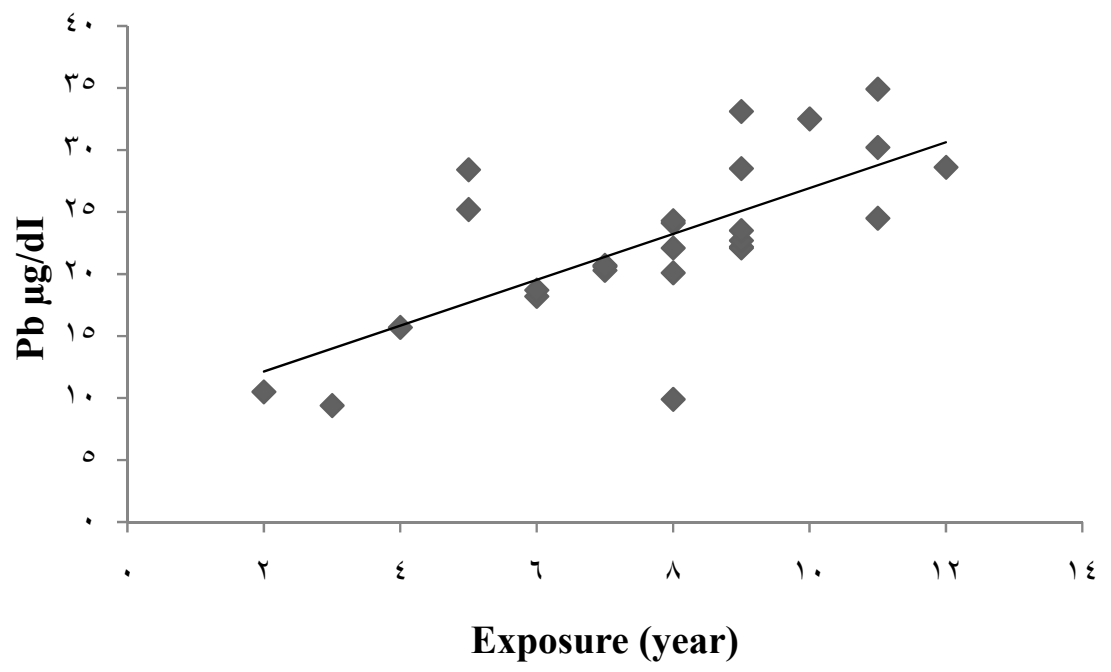

Figure r. Correlation coefficient between blood lead levels and duration of exposure in radiator repairing workers group.

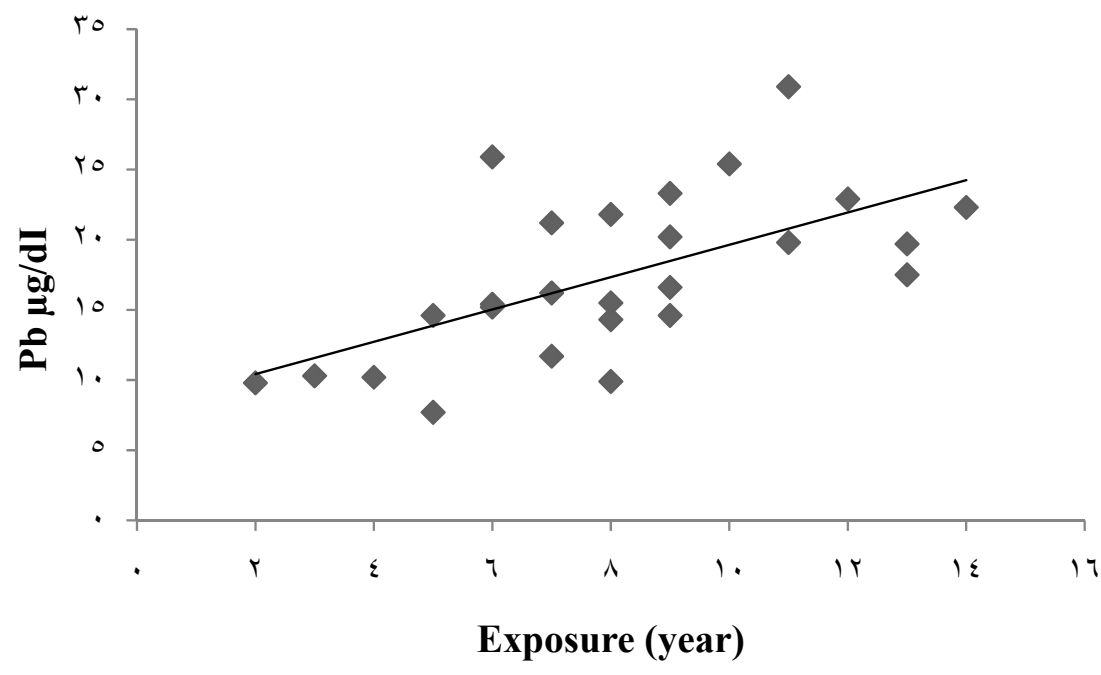

Figure r. Correlation coefficient between blood lead levels and duration of exposure in battery repairing workers group. 


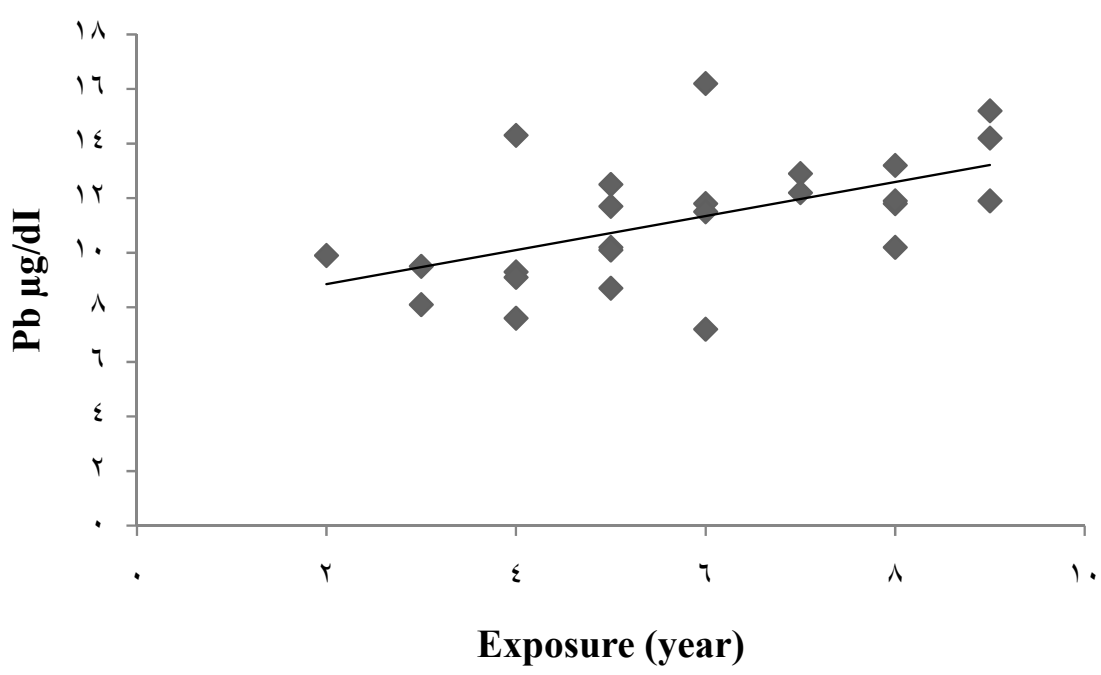

Figure $\varepsilon$. Correlation coefficient between blood lead levels and duration of exposure in gasoline power generator workers group.

\section{Discussion}

In general, the standard analysis of blood lead levels performed in laboratories around the world remains the most useful index of recent exposure ${ }^{r}$. The US centers for disease control and prevention intervention level reported a higher blood lead levels if it is $\geq 1 \cdot \mu \mathrm{g} / \mathrm{dL}^{\prime}$, and considered a cause for public health concern "r.

This survey documented occupational lead contamination from elevated blood lead levels in Erbil city among workers in work places with materials containing lead.

The significant difference between blood lead levels in control group, radiator, and battery repairing workers leaves little doubts that regular exposure to lead during their work is associated with increased blood lead levels. This give us that these workers exposed to lead during their working by inhalation, dermal contact (without using gloves) and ingestion from lips and contaminated hands. Similar were reported by many workers ${ }^{1 \%-19}$.
A significant difference was found ils in male control $\mathrm{s}$ workers. This is because some of the workers had been exposed in the past to lead during mixing preparing of ink and hand link with lead ovens and old machines. Some others workers exposed to lead through hand link and preparing of color inks. This result is inconsistence with the results reported by others $^{i n, r \cdot r !}$.

There was insignificant difference in mean blood lead levels between control and gasoline power generator workers groups. This result is in agreement with Al-Dosky et al. ${ }^{r}$, who were indicated that gasoline power generator workers exposed to lead didn't constitute a great health problem. While Al-Shayeb and Bounessah $^{r r}$ reported that gasoline combustion represent the source of $9 \leqslant . \wedge \%$ of the total lead in the atmosphere.

A significant correlation was found between blood lead level and duration of exposure in printing presses, radiators and batteries repairing workers. These result 
are consistent with other studies ${ }^{r, r \leqslant, r o}$. While, the duration of exposure in gasoline power generator workers showed nonsignificant correlation with blood lead levels, because most of these workers are not fixed in their working place during the operation of these generators.

All working groups show nonsignificant correlation between ages and blood lead levels, as the individuals who included in this study were adult not children or elderly.

In conclusion, blood lead levels were elevated in printing, battery, radiator repairing workers. Blood lead levels correlated with duration of lead exposure in printing, battery, and radiator workers, but not with their ages.

\section{References}

1. Pattee $\mathrm{OH}$, Pain DJ. Lead in the environment Chapter 10 In Hoffman DJ, Rattner BA, Burton JrGA, Cairns JrJ (eds ) Handbook of ecotoxicology Lewis Publ Boca Raton r...r; P rVr. $\varepsilon \cdot \wedge$.

r. Verity MA. Toxic disorders. In Graham DI, Lantos PL, eds Greenfield's neuropathology 'th eds Arnold London 199v;(1) v00_-11).

r. Matte TD, Figueroa JP Ostrowski S, et al. Lead poisoning among household members exposed to leadacid battery repair shops in Kingston

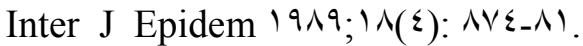

$\varepsilon$. Carolyn K. Lead contamination in our environment Yale-New Haven Institute 199v; 1:10_11.

- Goyer R. Toxic and essential metal interactions Annu Rev Nutr 1997; Y V:rV_o.
7. Gossel TH, Bricker J. Principles of Clinical Toxicology rd $^{\text {rd }}$ edit New York 199 ; p 19v.

V. Thomas E, Andreoli MD, Charles E, Carpenter MD. Cecil essentials of Medicine Tth edit $r \ldots \leqslant ; p \leqslant 0 \Lambda$.

$\wedge$. James R, Randy N, Leonare N. The association between environmental lead exposure and bone density. Environ Health Perespec r...ร; r:Ir...r.

१. Richard L. Very low lead linked with IQ deficits Ace Natio Engl J r.. $\leqslant ; r) \cdot: 0 r \cdot-r l$.

1.. WHO (World Health Organization) Lead Environmental Health Criteria. 1990; V. 170 Geneva .

1). Pineau A, Fauconneau B, Rafael M, et al. Determination of lead in whole blood: comparisons of the LeadCare blood lead testing system with Zeeman longitudinal electrothermal AAS. J Trace Elem Med Biol r...r; $(r): 11 r_{-} \mid V$.

IY. Kim HS, Lee SS, Hwangbo Y, et al. Cross-sectional study of blood lead effects on iron status in Korean lead workers. Nutrition $r \cdots r ; 19\left(V \_\Lambda\right): O V /$ $\mathrm{VI}$.

1r. Williams G, Hall L, Addae J. Increase in hair lead but not blood lead content of occupationallyexposed workers. Environ Geochem Health 199А; $r \cdot: r r q-\varepsilon r$.

1). Hodgkins DG, Robins TG, Hinkamp DL. A longitudinal study of the relation of lead in blood to lead in air concentrations among battery workers. $\mathrm{Br} J$ Ind Med $1994 ;\{9: Y \leqslant 1-\Lambda$.

10. Fletcher AM, Gelberg KH, Marshall EG. Reasons for testing and exposure 
sources among women of childbearing age with moderate blood lead levels $\mathrm{J}$ Comm Health 1999; $r \varepsilon(r): r 10_{-} r v$.

17. Tozun M, Unsal A, Birmagul B. The lead exposed among lead workers: an epidemiological study from west Turkey. Iranian $J$ Publ Health r.. 9;rA (r): TO-VA.

IV. Ahmed K, Ayana G, Engidawork E. Lead exposure study works in lead acid battery repair units of transport service enterprises Addis Ababa, Ethiopia a cross-sectional study. J

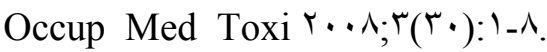

1^. Lai JS Wu TN Liou SH, et al. A study of the relationship between ambient lead and blood lead among lead battery workers. Inter Arch Occup Environ Health

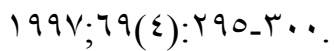

19. Hwang YH, Chao KY, Chang CW, et al. Lead as an alternative measure for lead exposure assessment of lead battery assembly workers A I H A J r...; ; ( ( ):ArO_r!.

$r$. Oke PR, Brassington GB, Griffin DA, Schiller A The Bluelink ocean data assimilation system. Ocean Modeling

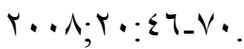

Y). Galal S, El-Samra GH, Mazhar M, et al. Risk behaviour of lead-exposed workers and hearing impairment. IJCRIMPH $r^{\prime} 11 ; r(r): 1 r_{-} \varepsilon r$.

Yr. Al Dosky AH, Al-Timimi DJ, AlDabbagh SA. Occupational exposure to lead in Duhok City Kurdistan Region Iraq Duhok Med J Y. 11:0(r):VT_Ao.

rr. Al Shayeb SM, Bounessah M. Lead levels in atmospheric deposited dust from petrol stations and roadsides in Riyadh City Saudi Arabia STCEX r...r; Pr. I-r.v.

$r \varepsilon$. Mehdi JK, Al Imarah FJM, Al Suhail AA. Levels of some trace metals and related enzymes in workers at storagebattery factories in Iraq Eastern Med Health J Y...; ฯ( ( ): $\vee^{\prime} \tau_{-}$.

ro. Al Khalidy KSH, Chabuk AJAK, Kadhim MMA. Measurement of lead pollution in the air of Babylon Governorate/Iraq during year $Y \cdot 1$. World Acad Sci Eng Tech r. Tr:Tr:Arr-q. 